British Post Office and manufactured by Submarine Cables, Ltd. The first is an additional cable between Nevin (North Wales) and Howth (Eire). The second connects Dartmouth (Devonshire) and Guernsey and the third is laid between Guernsey and Jersey. The cables are of the concentric type insulated by paragutta and, with the exception of the sheathing, which is made suitable to the conditions prevailing round the British Isles, are similar to the cable laid three years ago from Australia across the Bass Strait. The C.S. Faraday left Greenwich in July 1938 carrying the Anglo-Eire and the two Channel Islands cables, weighing in all 1,440 tons. When the cable had been laid for ten miles from Nevin, a dense fog came on which completely obscured the buoys marking the course, but nevertheless the ship proceeded on its course and luckily sighted a marked buoy when the fog cleared. The submarine cables are operated by two carrier frequency systems the terminals of which are at Dublin and Nevin, with intermediate repeaters at Howth. The two concentric cables carry eighteen telegraph and fifteen telephone circuits. The laying of the Channel Islands cables presented little difficulty. A single core cable, which had formerly been part of an Atlantic telegraph cable, was relaid in 1914 between Compass Cove, near Dartmouth and Plemont, Jersey. In 1931 this was diverted into Saints Bay, Guernsey, to provide a telephone channel between England and Guernsey. The new cables provide two telephone circuits between England and Guernsey, and six telephone circuits between England and Jersey.

\section{Progress of the Grid}

THE report of the Central Electricity Board for the year 1938 is very satisfactory, although there was a slight reduction in the rate of increase at which electric power is being generated. For the first time since 1932, this rate of increase fell below 10 per cent per annum. The aggregate production is still substantially in excess of the estimates adopted by the Board and those made by the commissioners when planning the various grid schemes. The total output of electricity from public supply stations was 24,400 million units, an increase of nearly 1,500 million units over the previous year. Apparently the stimulus provided by the re-armament programme made up for the loss in demand of the shipbuilding, textile and other industries. At the end of 1938, the grid comprised 4,378 miles of transmission lines, nearly 3,000 miles of which operated at 132 kilovolts, the remainder operating at 66 kilovolts or less. The number of selected stations remained constant at 137 and their total installed capacity was more than $8 \frac{1}{4}$ million kilowatts. During the year, the Board investigated special air raid precautions. It was decided to provide a pool of switchgear, transformers and other equipment, which could readily be made available to replace, temporarily, apparatus that might be damaged. The research work into surges, defective lightning arresters and other troubles arising from atmospheric effects was continued throughout the year. Alterations were also made on switchgear so as to increase their rupturing capacity. The average cost of fuel per ton was 14s. 9d. in 1937 and $20 s .3 d$. in 1938. This increased cost of fuel more than counterbalanced the benefits which would otherwise have accrued to electricity consumers from the improved efficiency of generation.

\section{Electric Development in South Africa}

THE rapid economic development of South Africa during the last twenty years is illustrated by the remarkable growth that has taken place in the development of electricity both for industrial and domestic purposes. The extent to which the Union of South Africa is electrified is shown by the sales of electrical energy being 1,670 units per head of population per annum (excluding natives). This figure is twice that for the United States of America and nearly four times the corresponding figure for Great Britain. In a paper on "South African Activity" by H. A. Eastman, published in the Electrical Review for June 2, some of the reasons for this rapid and continuing growth are given. Three fifths of the total demand for electricity is due to the requirements for gold mining purposes. When the numerous mines in process of development are brought to the production stage, this will be greatly increased. The use of electricity for other industries and for domestic purposes is also increasing. The average price received by the generating stations is $0 \cdot 6 d$. per unit. The Electricity Act which came into force in 1922 provided for the establishment of an Electricity Control Board, which is the licensing and controlling authority for all private electricity undertakings. It also controls the Electricity Supply Commission, the members of which are appointed by the Government, but which, nevertheless, is free from parliamentary control. The Electricity Supply Commission operates its undertakings at neither a profit nor a loss and adjusts its charges accordingly. Other licencees are required to refund each year to their consumers, pro rata to their payments, 25 per cent of the surplus profits of the undertaking for that year.

\section{Baking Quality Tests for Flour}

Is 1934 the Imperial Bureau of Plant Breeding and Genetics published its first bibliography of papers on baking quality tests, which was an immediate success, and in a new supplement recently issued (Imperial Bureau of Plant Breeding and Genetics. Bibliography of Baking Quality Tests, Supplement. Pp. 32. Cambridge: School of Agriculture, 1939. 1s. 6d.) the Bureau has fully maintained the high standard it set itself in the earlier publication. A list of more than three hundred and thirty titles to original papers is given here, set out in alphabetical order. The list is remarkably complete and no really important communication appears to have been overlooked. One excellent feature of this bibliography which greatly commends it is the translation of the titles of the foreign publications into English. At the present time, extensive investigations are being made in Great Britain and abroad on the physical 